\title{
The Role of a Lecturer's Performance in Facilitating Problem Solving for Students in Learning Translation (A Case Study of a Good Lecturer at UKI Toraja, Indonesia)
}

\author{
Judith Ratu Tandi Arrang \\ Arifuddin Hamra \\ Baso Jabu \\ judith_ratu@yahoo.com \\ Graduate Program \\ State University of Makassar, Indonesia
}

\begin{abstract}
The objectives of the research are to find out (i) the problems that the lecturer faces in teaching translation; and (ii) the way of lecturer solves the problems in teaching translation. The researcher employed qualitative method in form of naturalistic approaches for the study. The data resources for the research included one lecturer and students. The instrument for the research consisted of observation, interview and document files. In analyzing the data, the researcher employed cyclical model by Miles and Huberman. The results showed that, (i) the problems that the lecturer faced were from students themselves: lack of vocabulary, lack of knowledge in grammar-structure, semantic, unmotivated student or passive students, students were difficult in looking up the word in the dictionary, the students tended to use translation machine and another problem was from outside the student was lack of advanced dictionary; (ii) the lecturer solved the problems by reviewing the material, simplifying the material by taking very close examples, using more than one language in teaching, giving tips to translate, approaching the students by asking questions, organizing the class and providing quiz, exercises, assignments, and providing advanced dictionary, and comparing the use of translation theory than translation machine in translating.
\end{abstract}

Key words: lecturer performance, teaching translation, problem solving

\section{INTRODUCTION}

International communication is mainly performed in English. Knowledge of this language is a basic condition for getting access to the world of scientific literature, doing business with foreign partners, and integrating into foreign markets.

Then translation plays an important role for rendering some information. Duff (1994) states that translation happens everywhere and any time. EFL college students require translation skills in their daily lives. 
In some real situations, EFL students must use their translation skill to operate the computer, to get more literatures that are written in English, or to explain the medication direction to their parents by translating from English to Indonesian.

In classroom interaction, the students translate in class for other students, and interpret signs and notices in the environment. When integrated into daily classroom activities, translation can help students to develop and to improve reading, speaking, writing skills, grammar, and vocabulary (Dagilienè: 2012). This statement is supported by Gabreliatos (1998) who stated that translation is most frequently used as a convenient shortcut when teaching vocabulary by providing 'equivalents' in the learners' mother tongue.

However, translation is used in teaching and learning practice, students still do common errors in translating. According to Lin (2008), students are still challenged to make a perfect match in meaning and style between the two languages. Therefore, errors inevitably occur in their translations. In addition, Tang (1995) concluded that students' errors might be attributed to a failure in comprehension and expression. The comprehension problem was primarily due to inadequate understanding of the original meaning. Accordingly, the meaning was modified or twisted. The original meaning was at times inflated, subdued, or concocted in the translated meaning.

Relating to the common errors that is done by the students, there are many factors that influence the students to get their achievement such as: students themselves, lecturer, method, material, time, facilities, and classroom environment. Lecturer can choose a particular method by seeing some factors from the students such as: the background of the learners, the level of English proficiency, the circumstances they will face in the future, and the objectives of the lesson and classroom condition. However, many studies have been examined today about teaching method, but no one claims that one is better than other'.

The most important factors in a classroom situation are the interactions and exchange initiated by teacher and students (Flander, 1970). There will be a process whereby two or more people are engaged in reciprocal actions. These actions may be verbal or nonverbal (Celce-Murcia, 2002). The interaction can be verbal exchange, asking questions, responding and reacting. 
According to Hattie (1999:74), lecturer's responsibility is to help the students to get their higher performance in learning. It requires a special skill, intelligence and quality from teachers to bring the students to get their higher achievement.

To know what the students need, always motivated in teaching and have a good interaction in classroom in order to have an effective teaching. Effective teaching means the lecturer can engage students in the teaching-learning process and help them develop critical thinking skills.

Effective teaching relates to effective teachers. Effective teachers can draw the students to get their higher performance by understanding the subject knowledge, respecting the students, applying interesting teaching styles, and applying the good communication with the students with good interaction in classroom (Aregbeyen, 2010).

Related to an effective lecturer or being a good quality of lecturer, he/she should be a competent one. Lecturer should apply broad, deep and integrated sets of knowledge and skills as they plan, implement, and revise instruction in their performance in the classroom. Apparently, when thinking about competences, concepts such as performance and effectiveness are involved because competence is directly linked with effective performance in complex situations as it is thought to serve as a causal factor for success (Westera, 2001).

Explanation above shows us that teaching performance becomes very important in general area or study of education. It is probably because the performance of the lecturer plays an important role in successful students. This role of teaching performance is also done by the lecturer of English Study Program of UKI Toraja. Pre-observation in classroom at lecturer's training program for Active Learning in School (ALIS) and Active Learning in Higher Education (ALIHE), and from some positive comments from the alumnus and colleagues showed that there is a translation lecturer at English Education Study Program who is competent and good in his performance.

The alumni thought that he was a good lecturer, he could facilitate students in learning, for examples: different methods, using aids and implemented the kind of cooperatives learning in teaching-learning process. In addition, he has been teaching English since 2002 in informal institution and has been being a lecturer at UKI Toraja since 2006. Moreover, considering the existing data from previous semesters, it showed that he got good level of students' satisfaction of his teaching performance. 
This research was designed to find out the role of a lecturer's performance in teaching translation. It was aimed at answering the questions: "(1) what problems do the lecturer face in teaching translation?; and (2) how does the lecturer solve the problem?".

Therefore, this study is important because the results provide some important information theoretically and practically about the role of the lecturer's performance in teaching translation particularly in solving the problems.

\section{REVIEW OF LITERATURE}

\section{The Concept of Teaching Translation}

Popovic (1996) stated that there were five things as consideration when lecturer wants to teach translation: level and age of the students, direction, organization, content - what to focus on practice, and how to integrate translation in existing courses.

\section{Level and age of the students}

Doing translation demands cognitive process. Hence, the lecturer or teacher needs to know the level or age of their students. The lecturer needs to think about what kind of activities can be successful to be applied in the classroom, make some considerations by seeing what the students' preference, pedagogical objectives, and the context or situation in teaching.

\section{Direction}

There will be two processes of translation. First, translate from source language into target language. The second is translating target language into source language. It will demand more tasks. Lecturer needs to be aware about the levels of the students. Hence, this is the initial stages of learning.

\section{Organization}

Lecturer needs to decide about the translation activities and choose the appropriate forms of classroom interaction. There will be a distribution process and teacher can do translation in integrated skills such as in reading, writing, and listening activities. The lecturer can make a group discussion or students can do translation in pairs that the students get a chance to work, share, test, and compare their ideas. 
174| ELT Worldwide Vol. 3 No. 2 October 2016

\section{Content - focus on practice}

Arthur (1995:59) in Popoviv states that translation activity pursued in an EFL classroom ought to meet the following criteria:

Language is used for a purpose, they create a desire for communication, they encourage students to be creative and contribute their ideas, students are focused on what they are saying rather than how they are saying it. Students work independently, and determine what they want to say or write.

In the literature, two types of approaches to translation are suggested: top-down, from the macro to the micro level, theoretically more valid; and bottom-up, much easier to follow for those who have no previous training in linguistics (Baker 1992:6). Course books on translation are a useful source for the identification of problematic areas.

\section{How to integrate translation in existing courses}

Eadie (1999) states that there will be some activities in teaching translation: preparatory activities, or pre-translation activities, prewriting, or post-reading, or grammar or vocabulary practical tasks. In addition, translation activities can occasionally be employed for consolidation, while post translation activities may be focused on rewording, rewriting, revision and evaluation. The following steps as follows:

1) Pre-translation activity

Aim : To integrate translation and reading skills in order to activate schemata

Step 1: The teacher initiates a discussion on the topic to be dealt with in the class. She elicits key words in L2 from the students. She writes the words the students do not know (but which appear in the text) in L1.

Step 2: The students read the text in pairs or small groups. Try to find L2 equivalents of the words written on the board.

Step 3: The whole class compares results.

2) Pre-translation activity

Aim : To integrate vocabulary practice and writing with translation.

Step 1 : Vocabulary practice. 
a) How many of the following verbs can be used with an inanimate object?

b) Try them with the following subject:

This paper

reveal aim consider examine document indicate show describe report present identify develop maintain view stress contend comment state hold question detail see put forward investigate deal with

Step 2 : Would you use a direct translation of these collocations in your mother tongue?

Translation activity

Aim : Raising awareness of the role of context and register.

Step 1 : Divide the text into three parts, A, B and C; form groups of three and give each a different section to translate.

Step 2 : The students who were given the same portion of the text form new groups of three in which they compare and discuss their translations. They also try to agree on a best version.

Step 3 : The students go back to their original groups, put the translated text together, discuss it and make necessary changes.

3) Post-translation activity

Aim : Raising linguistic awareness through translation.

Step 1: The students compare and discuss their versions and fill in a comparison chart.

Determine the steps in teaching-learning process help the lecturer to be focus on reaching the goal of the lesson. Furthermore, the students are drawn into the right way of the learning process to reach the goal.

\section{The Role of Lecturer in Classroom Interaction}

Hamra \& Syatriana (2012) state that the role of the lecturer plays important role in teaching and learning process. The teachers/lecturers have several roles in the classroom. According to Harmer (2003:57), teachers can be a controller, an organizer, an assessor, a prompter, a participant and resource.

\section{Controller}

Teachers as controllers are in charge of the class and of the activities going on in groups. This control is not the most effective role for the teacher to adopt. 
176| ELT Worldwide Vol. 3 No. 2 October 2016

This role is useful during the accurate reproduction stage of the lesson and in frontal activities. At the practice stage and especially at the production stage of the lesson this control should be relaxed to some degree (Harmer, 2003:57).

\section{Organizer}

Organizing students to do various activities is one of the most important roles that teachers have. It involves giving the students information, defining the work forms in the classroom and organizing teaching material. Skillful classroom management involves the following areas:

1) Organizing the environment which means decorating the walls of the classroom with culture-related posters, maps, flags etc. And arranging the desks and chairs so that the students can learn in different work-forms (in group-, pair-work etc.);

2) Organizing the children according to language proficiency or language abilities;

3) Organizing activities, the ideal balance of skills and activities should be maintained. After each stirring activity a settling activity must be planned, and various skills should be developed in different workforms;

4) Organizing time in an average lesson maximum five minutes. It must be devoted to a warm-up activity which is followed by the so-called 3Ps (presentation, practice and production with about ten-fifteen minutes spent on each). The last period of lesson is to be spent on revision and giving feedback to the students;

5) Organizing resources that is as important an area as the ones mentioned previously, because all types of teaching material such as the course book, the workbook, handouts, cassettes etc. must be kept in a well-organized way so that the teacher can use them smoothly without making a chaos;

6) Organizing records which is considered to be a crucial element of classroom management. All the teachers have to think of as their handling has proper legal consequences as well;

7) Organizing your self. It is the last but perhaps it becomes the most important element of organization as all the teachers are human beings with many private problems that their students cannot feel. Before entering the classroom, teachers should leave their problems outdoors and focus on the work taking place inside.

\section{Assessor}

A major part of a teacher's job is to assess the students' work, to see how well they are performing and how well they have performed. The different types of error correction must be distinguished. 
At the accurate reproduction stage, where the teacher is totally in control, she/he must be correcting each student's error or mistake. When students are involved in immediate creativity (at the production stage of the lesson), gentle or delayed correction should be used. A distinction between two kinds of feedback must be made. Content feedback concerns an assessment of how well the students performed the activity as an activity rather than as a language exercise. Form feedback, on the other hand, tells students about how well they performed in terms of the accurate use of language. Content feedback should usually come first and the teacher must decide when form feedback is appropriate and when it is not. It is vital for the teacher to be sensitive and tactful to his/her students in his/her role as assessor and to start assessment always with the positive feedback.

\section{Prompter}

In this role, the teacher needs to encourage students to participate in a role-play activity or to make suggestions about how students may proceed in an activity. The role of prompter has to be performed with discretion because if the teacher is too aggressive, she/he will take over the jobs from the students and he will make the students become lazy and passive.

\section{Participant}

Teachers should not be afraid to participate in certain activities as a partner. Nonetheless, she/he should not get involved in pair-work or group-work because it will prevent her/him from monitoring the students and performing other important roles.

\section{Resource}

Teachers used to be the only resource of information. However, this role should not be performed these days as it was done several decades ago. Students have an access to the Internet and other important sources so teachers can add only some pieces of information to the ones gained from other sources. Teachers are supposed to organize and coordinate the process of acquisition, to act as a catalyst.

Those lines above are supported by Harmer (2001) who states that these roles are frequently interrelated (e.g. assessor and observer). The roles of a consultant or co-communicator encourage classroom interaction but they need the support of other roles (e.g. for organizing and controlling activities). 
178| ELT Worldwide Vol. 3 No. 2 October 2016

\section{The problems in translation}

In doing translation, translator faces many problems. Soemarno (2000: 1) says that the difficulties are not only the vocabulary but also the word structure. Another difficulty is in the process of transferring the meaning from source language into the target language such as: word arrangement, sentence pattern, kinds of word, and suffix. When translating English into Indonesian or vice versa, the translator creates misunderstanding or they face difficulty in translating the messages. Then, the translator deals with many problems of meaning such as lexical meaning, grammatical meaning, contextual meaning, textual meaning, and socio-cultural meaning.

\section{Lexical meaning}

Lexical meaning is a meaning which is explained in the dictionary. Kridalaksana (in Nababan, 2003: 48) says that lexical meanings of words are out of the context. For example, The English word 'bad' may mean jahat, buruk, jelek, susah, tidak enak and busuk in Indonesian.

\section{Grammatical meaning}

Nababan (2003: 49) says that grammatical meaning is the relationship of the parts of language in the wider units, for example: the relationship between word and the other words in a phrase or clause. Example: "they can the fish". (can means 'memasukkan dalam kaleng' and function as a predicate) and "he kicked the can hard". (can means 'kaleng' and functions as an object).

\section{Contextual meaning}

Contextual meaning is the relationship between the utterances and the situation where the utterances are used (Nababan, 2003:49). In other words, contextual meaning is a meaning that is correlated with the situation where the language is used. Example: "Good morning!" The utterance might have two meanings; the first meaning is "selamat pagi". Besides, it can also mean "keluar" if it is said by a leader to the officers who come late.

\section{Textual meaning}

Textual meaning is related to the context of a text (Nababan, 2003: 50). It is found in a discourse or a text. For example, the word 'morphology' in the science of Biology means 'the scientific study of the form and structure of animals and plants'. 
In Linguistics, the word 'morphology' means 'study of the morphemes of a language and how they are combined to make words'.

\section{Socio- cultural meaning}

Socio-cultural meaning is meaning which is closely related to the social situation and cultural background of the language users (Nababan, 2003: 50). Example: A friend is walking in front of A's house.

A: "Hai mau ke mana?"

B: "Mau kesana, sedang apa?"

A: "Berkebun. Mari singgah."

B: "Terima kasih. Sudah siang. Lain kali ya."

\section{Translation Quality}

According to Akil (2007), to make a clear-cut in grading, the three criteria should be weighted. The first is weighted 1 (one), the second is weighted 2 (two), the third is weighted 1 (one). The reason for giving higher weigh to the second is that the most important point in translation is message rendering.

Here is the example of the way Akil (2007) assess the students:

Example of application: Let say a student is assigned to translate the Indonesian sentence, “ Anda anak ke berapa?" and the student's translation is, "What is your birth position?" This translation is grammatically correct, so in terms of accuracy, it is scored 1. It is also understandable, but it needs time to think before getting the idea. Then it is scored 1 in terms of clarity. However, since that is not the natural way to say that in English, so in terms of naturalness, it is scored 0. Then, the student's grade is $2(0-4$ grading scale $)$.

\section{METHOD}

The researcher employed qualitative method in form of naturalistic approaches for the study. The data resources for the research included one lecturer, students, and colleagues. The instrument for the research consisted of observation, interview and document files. In analyzing the data, the researcher employed cyclical model introduced by Miles and Huberman. 


\section{FINDINGS}

\section{The Problems That the Lecturer Faces In Teaching Translation}

Table 1 Data Display for Some Problems faced by The Lecturer in Teaching Translation

\begin{tabular}{|c|c|c|c|}
\hline No & Types of Problems & $\begin{array}{c}\text { The Way of the Lecturer deals } \\
\text { with the problem }\end{array}$ & Source \\
\hline 1 & $\begin{array}{l}\text { Extract 1: Lacking of } \\
\text { vocabulary of the } \\
\text { students }\end{array}$ & $\begin{array}{l}\text { My problem is caused by less } \\
\text { vocabulary. } \\
\text { Many problems, specially for } \\
\text { vocabulary. }\end{array}$ & $\begin{array}{l}\text { S3.24 interview } \\
\text { S4.17Interview }\end{array}$ \\
\hline & & $\begin{array}{l}\text { Actually that problem is by me. } \\
\text { because I have less vocabulary } \\
\text { and I am a slow learner. } \\
\text {..the biggest challenge is their } \\
\text { vocabulary is still very low,... } \\
\text { moreover their knowledge of } \\
\text { semantics.... }\end{array}$ & VS.15/ interview \\
\hline 2 & $\begin{array}{l}\text { Extract 2: Lacking of } \\
\text { knowledge in } \\
\text { grammar-structure of } \\
\text { the students }\end{array}$ & $\begin{array}{l}\text { If we talk about the problem } \\
\text { especially in translation, maybe } \\
\text { it causes by less structure and } \\
\text { vocabularies. I think so. }\end{array}$ & S1.18/interview \\
\hline & & $\begin{array}{l}\text { My problem is while translating } \\
\text { it was difficult to distinguish } \\
\text { whether it has appropriated with } \\
\text { context or gramatical. }\end{array}$ & S3.30/interview \\
\hline 3 & $\begin{array}{l}\text { Extract } 3 \text { : Lacking of } \\
\text { advanced dictionary }\end{array}$ & $\begin{array}{l}\text {.., knowledge of grammar is } \\
\text { low, .... Let's just say that their } \\
\text { English level is still very low, } \\
\text { and translation needs sufficient } \\
\text { English experience. }\end{array}$ & VS.15/interview \\
\hline 4 & $\begin{array}{l}\text { Extract 4: Facing } \\
\text { unmotivate or passive } \\
\text { students }\end{array}$ & $\begin{array}{l}\ldots, \text { I have no good dictionary } \\
\text { because a lack of a good book } \\
\text { store here.... }\end{array}$ & S6.18/interview \\
\hline 5 & $\begin{array}{l}\text { Extract 5: Facing } \\
\text { difficulty in looking up } \\
\text { the words in dictionary }\end{array}$ & $\begin{array}{l}\text { Because as we know that most } \\
\text { of our students are passive } \\
\text { learners, .... }\end{array}$ & VS.12/interview \\
\hline 6 & $\begin{array}{l}\text { Extra 6: using machine } \\
\text { translation by the } \\
\text { students }\end{array}$ & $\begin{array}{l}\text {... my weakness is I can not find } \\
\text { the word quickly } \\
\text { I'm slow in opening the } \\
\text { dictionary. } \\
\text { That the students tend to use } \\
\text { machine translation, for example } \\
\text { google translation. }\end{array}$ & $\begin{array}{l}\text { S1.24/interview } \\
\text { S4.19/interview } \\
\text { VS.44/interview } \\
\text { FN.1/observation }\end{array}$ \\
\hline
\end{tabular}




\section{The Way of the Lecturer Solves the Problems}

Table 2 Data Display of the Way of Lecturer Solves Problems in Teaching Translation

\begin{tabular}{|c|c|c|c|}
\hline No. & $\begin{array}{c}\text { Types of } \\
\text { strategy to Solve } \\
\text { the problem }\end{array}$ & The Way of the Lecturer Solves the Problem & Source \\
\hline 1 & $\begin{array}{l}\text { Extract 7: } \\
\text { Simplifying the } \\
\text { material by } \\
\text { taking very } \\
\text { close examples }\end{array}$ & $\begin{array}{l}\text { He drew scheme on the board to explain and to } \\
\text { give example "brunch" is derived from two words } \\
\text { "breakfast" and "lunch". he gave example of } \\
\text { blending in bahasa Indonesia: "Hansip" derived } \\
\text { from the words "pertahan + sipil". } \\
\text { I teach them as simply as possible by taking } \\
\text { examples that are very close to them. I take the } \\
\text { examples around them to get them understand } \\
\text { easily. So we don't need to depend only on the } \\
\text { textbook. I use simple and familiar examples } \\
\text { He always makes those materials be simple and } \\
\text { easy to be understood by his students. He gives us } \\
\text { example that we can be remembered all the time } \\
\text { Because the way he teaches is easy to be } \\
\text { understood. Its so simple. }\end{array}$ & $\begin{array}{l}\text { S1.10 } \\
\text { interview } \\
\text { S2.14 } \\
\text { interview }\end{array}$ \\
\hline 2 & $\begin{array}{l}\text { Extract 8: } \\
\text { Approaching } \\
\text { unmotivated or } \\
\text { passive students }\end{array}$ & $\begin{array}{l}\text { He approached the students and let the students ask } \\
\text { if they find difficulties. } \\
\text { I usually move from one corner to the others, ... I } \\
\text { do not stay at my table during the class but, I move } \\
\text { to watch them and if I find a student be passive, I } \\
\text { approach him/her and ask a question of or ask if } \\
\text { he/she finds difficulties. } \\
\text {... he approaches us one by one . after he explaining } \\
\text { the the material,.... } \\
\text {...when we face difficulty, for example we don't } \\
\text { know to ask, he will come beside to guide us. }\end{array}$ & $\begin{array}{l}\text { FN1:A18 } \\
\text { observation } \\
\text { VS.14 } \\
\text { interview } \\
\\
\text { S6.12 } \\
\text { interview } \\
\text { S7. } 8 \\
\text { interview }\end{array}$ \\
\hline 3 & $\begin{array}{l}\text { Extract 9: } \\
\text { Using more than } \\
\text { one languages }\end{array}$ & $\begin{array}{l}\text { I sometimes speak three languages. } \\
\text { After he speaks English, then he translated in } \\
\text { Indonesian } \\
\text {...after giving instruction in English for example I } \\
\text { tried to translate it again. }\end{array}$ & $\begin{array}{l}\text { VS.18 } \\
\text { Interview } \\
\text { S2.26 } \\
\text { interview } \\
\text { VS.6 } \\
\text { Interview }\end{array}$ \\
\hline
\end{tabular}




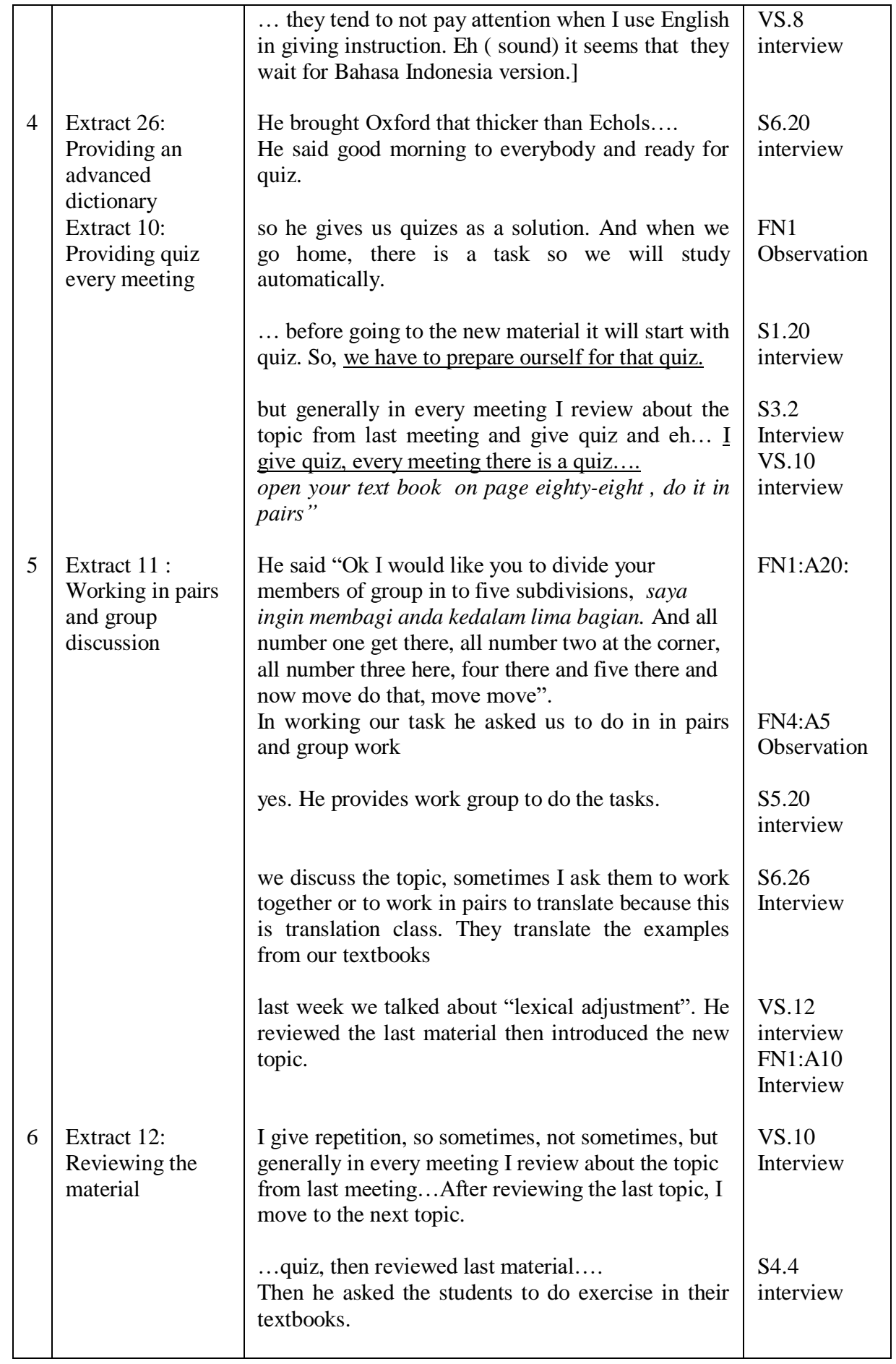




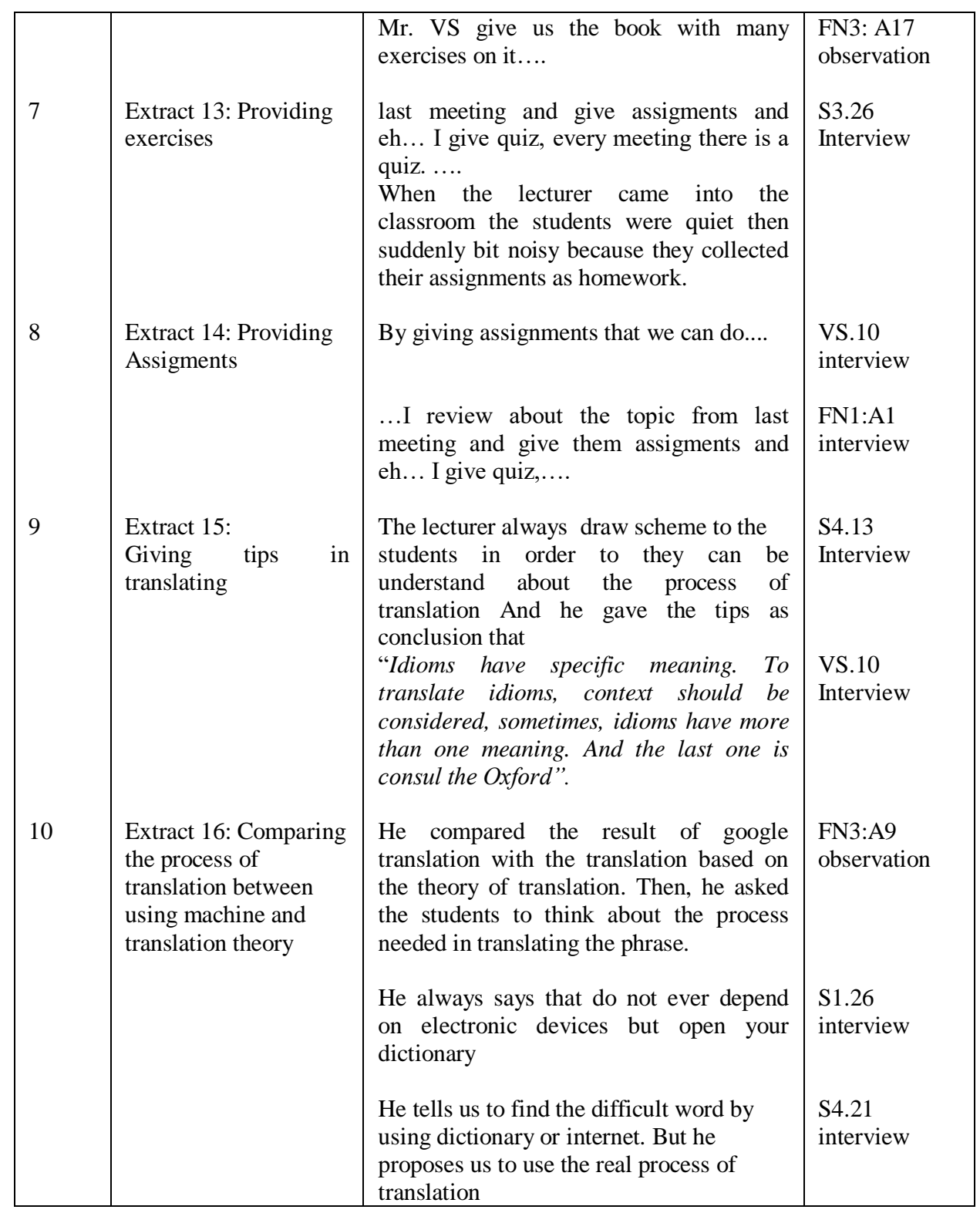

\section{DISCUSSIONS}

\section{Problems faced by the lecturer in teaching translation}

Ali (2013) stated that there were some problems faced by the students in learning: (1) Linguistic problems include grammatical differences, lexical ambiguity and meaning ambiguity; (2) Culture is another major problem that facing translators; (3) Pragmatic translation problems; and (4) Textspecific problems. Moreover, Soemarno (2000: 1) says that the difficulties are not only the vocabulary but also the word structure. 
184| ELT Worldwide Vol. 3 No. 2 October 2016

The findings showed that lecturer' problems in teaching translation are influenced by some factors: (a) inside problems from the student. Helme and Clarke (2001) state that students need to have both the will (motivation) and the skill (capability) to be successful learners.

It is the experience of teachers that students who are motivated to learn and who think carefully about what they are learning and understanding of the material being covered. It means that students need to understand the material. Furthermore, to be good translators, students need to know about words. In fact, the students at English Education Study Program had (1) lack of vocabulary; (2) lack of knowledge in grammarstructure; (3) unmotivated student or passive students; (4) difficult in looking up a word in dictionary; and (5) they tend to use transition machine. (b) The outside problem was from the student who had lack of advanced dictionary.

\section{The way of translation lecturer solves the problems}

Considering some problems faced by the students - for those who were lack of vocabulary, lack of knowledge in grammar-structure and semantic - the lecturer applied the strategies by reviewing the material. Reviewing material can help the students to remember the previous material. The lecturer simplifies the material by taking very close examples. It is vital for the lecturer to explain clearly, be well prepared, summarize key points, and state objectives for each class session (Aregbeyen, 2010). Furthermore, in the classroom interaction VS used more than one language in teaching, and giving tips to translate.

Next, for the unmotivated students or passive students, the lecturer applied the strategies by approached them by asking questions, organizing the students to work in pairs and group discussion, providing quiz every meeting, providing exercises, providing assignments to engaged them in learning. Popovic (1996) explained the way to organize the activities in the classroom. It is about the role of the lecturer to organize the things that happened in the classroom. Furthermore, the students who were difficult to look up the words in dictionary, the lecturer asked the students not to rely on translation machine but to try to use their own dictionaries, and compare of translation theory works in translation. The last one is the problem outside the students. It is about the lack of advanced dictionary by providing some advanced dictionaries. The explanation above can be displayed as follows: 
Table 3 The Ways of the Translation Lecturer Solved the Problems

\begin{tabular}{lll}
\hline No & $\begin{array}{l}\text { Problems in Learning } \\
\text { Translation }\end{array}$ & Problem Solving by the Lecturer \\
\hline 1 & Lack of vocabulary & $\begin{array}{l}\text { Reviewing the material } \\
\text { Simplifying the material by taking very close examples } \\
\text { Using more than one language in teaching } \\
\text { Giving tips to translate. }\end{array}$ \\
3 & $\begin{array}{l}\text { Lack of knowledge in } \\
\text { grammar-structure } \\
\text { passive students }\end{array}$ & $\begin{array}{l}\text { Approached them by asking questions. } \\
\text { Organizing the students in working in pairs and group } \\
\text { discussion. } \\
\text { Providing quiz every meeting }\end{array}$ \\
4. & $\begin{array}{l}\text { Providing exercises, providing assignments to engaged them } \\
\text { in learning. }\end{array}$ \\
words in dictionary & $\begin{array}{l}\text { Lecturer asked the students not to rely on electric dictionary } \\
\text { but always try to open their own dictionary. }\end{array}$ \\
& $\begin{array}{l}\text { Lack of advanced } \\
\text { dictionary }\end{array}$ & Lecturer provided some advanced dictionaries. \\
6 & $\begin{array}{l}\text { Students tend to use } \\
\text { translation machine }\end{array}$ & $\begin{array}{l}\text { Comparing the use of translation theory then translation } \\
\text { machine in translating the long text/story. }\end{array}$ \\
\hline
\end{tabular}

\section{CONCLUSION}

1. The problems that lecturer faces in teaching translation are: (1) Inside problem of the students; and (2) outside problem of the students.

2. The way of translation lecturer solves the problems is by reviewing the material, simplifying the material by taking very close examples, use more than one language in teaching, give tips to translate, approached students by asking questions, organize the class and provide quiz, exercises, assignments, and provide advanced dictionary to engaged them in learning and asks the students to compare the way of translation theory works then machine translation.

\section{SUGGESTIONS}

It is suggested for the lecturers to employ a good preparation before teaching translation, to facilitate the students well in learning translation, and try to solve the problems that are faced by the students in learning translation. 
186| ELT Worldwide Vol. 3 No. 2 October 2016

\section{REFERENCES}

Akil, M. 2007. The Profile of Indonesian - English Translation Made by English Department Students of Higher Learning Institutions in Makassar. Unpublished Dissertation.

Aregbeyen,O. 2010. "Students' Perceptions of Effective Teaching and Effective Lecturer Characteristics at the University of Ibadan, Nigeria," Pakistan Journal of Social Sciences, vol. 7, no. 2, pp. 62-69.

Baker, M. 1992. In Other Words. London: Routlage.

Celce-Murcia,M. 2001. Teaching English as a Second or Foreign Language.

Celce-Murcia,M. 2002. Teaching English as a Second or Foreign Language, $3^{\text {rd }}$ Edition. USA: Heinle \& Heinle.

Dagilienè, I. 2012.Translation as a Learning Method in English Language Teaching. ISSN 1648-2824 KALBŲ STUDIJOS. 2012. 21 NR. * STUDIES ABOUT LANGUAGES. 2012. NO. 21.

Duff, A., 1994. Translation: Resource Books for Teachers. Oxford: Oxford University Press.

Flanders, N. 1970. Analyzing Teacher Behavior. New York: AddisonWesley.

Gabrielatos,C. 1998. Translation Imposibilities problem and opportunities for TEFL. TESOL Greece Newsletter, 60, December 1998.

Gedviliene, G. 2014.The Case of Lithuania and Belgium: Teachers and Students' Social Competence .Vytautas Magnus University, Kaunas, Lithuania. European Scientific Journal May 2014 edition vol.10, No.13 ISSN: 1857 - 7881 (Print) e - ISSN 1857- 7431.

Hamra,A.,\& Syatriana,E. 2012. A Model of Reading Teaching for EFL Student. State University of Makassar.

Harmer, J. 2003.The Practice of English Language Teaching. Harlow: Longman. 
Arrang, Hamra, Jabu : The Role of a Lecturer's ...|187

Harmer, J.2007.How Teach English.Second Edition. Longman.

Helme, S., \& Clarke, D. (2001). Identifying Cognitive Engagement in Mathematics Classroom.Mathematics Education Research Journal, 13,133-153.

Huberman,M.A. \& Miles, B. M. 1994. Qualitative Data Analysis. $2^{\text {nd }}$ Ed. SAGE Publication.

Jabu,B.2008. English Language Testing. Makassar: Badan Penerbit UNM.

Lin, C. C. 2008. Lectures. Tamkang University.

Nababan, M. R. 2003. Teori Menerjemah Bahasa Inggris. Pustaka Pelajar:Yogyakarta.

Popovic, R. 1996. The place of translation in Language Teaching.

Richards, J. C. \& Rodgers, T. S. 2001. ( $2^{\text {nd }}$ edition) Approaches and Methods in Language Teaching. Cambridge: Cambridge University Press.

Richards, J. C. 2001. Curriculum Developing in Languge Teaching.Cambridge University Press.

Tang, C. L. 1995. Language teaching and translation. In S. W. Chan \& D. E. Pollard(Eds.), An encyclopaedia of translation: ChineseEnglish English-Chinese (pp. 476-486).Shatin, N. T., Hong Kong : The Chinese University Press.

Westera, W. 2001. Competence in Education: A confusion of tongues. Journal of Curriculum Studies, 33, 75-88. 